\title{
Distribution of Households by Equivalent Income
}

\section{Case of Central Federal District regions in the Russian Federation}

\author{
Ruslan Sadyrtdinov, Dmitry Rodnyansky \\ Institute of Management, Economics and Finance \\ Kazan Federal University \\ Kazan, Russian Federation \\ s_ryslan@mail.ru,drodnyansky@gmail.com
}

\author{
Tatyana Strelnikova \\ Department of Economics, Management and Marketing \\ Finance University under the Government of the Russian \\ Federation (Lipetsk Branch) \\ Lipetsk, Russian Federation \\ kod219@mail.ru
}

\author{
Viktor Kolesnikov \\ Department of Accounting, Auditing and Statistics \\ Finance University under the Government of the Russian Federation (Lipetsk Branch) \\ Lipetsk, Russian Federation \\ glawbuch@lipetsk.ru
}

\begin{abstract}
Article presents the results of the Russian Federation household distribution by equivalent income in the form of stratification scale. Household equivalent incomes are estimated by authors using equivalence scales. Based on the research, the following conclusions are made. In almost all regions most households belong to the second group, which is considered to be the lower-middle class. The proportion differs throughout the regions, but on average it is $40 \%$ from the whole sample. Only in Moskovskaya oblast and Moscow city, most of households are in the third group which can be called the middle class. In the majority of Russian regions, the proportion of households below the relative poverty line is less than $10 \%$. Median equivalent income of households belonging to poor in terms of relative poverty does not exceed the subsistence minimum in the regions of the Central Federal District. The results can be used in the development and implementation of public policies aiming at overcoming poverty and improving the quality of life of the population of the Russian Federation.
\end{abstract}

Keywords-economics; equivalent income; poverty; region; Central Federal District; Russian Federation

\section{INTRODUCTION}

The Central Federal District (CFD) is situated in the center of the European part of Russia. The district consists of 18 regions of the Russian Federation: the city of Moscow, Bryanskaya oblast, Vladimirskaya oblast, Ivanovskaya oblast, Kaluzhskaya oblast, Kostromskaya oblast, Orlovskaya oblast, Ryazanskaya oblast, Smolenskaya oblast, Tverskaya oblast, Tulskaya oblast, Yaroslavskaya oblast, Belgorodskaya oblast, Voronezhskaya oblast, Lipetskaya oblast, Kurskaya oblast, Tambovskaya oblast and Moskovskaya oblast. The center of the district is the city of Moscow. Area of the district is 650.7 thousand square kilometers $-3.8 \%$ of territory of the Russian Federation. Population is more than 38 million people. By population density, the district ranks first among the federal districts (59.2 people $/ \mathrm{km}^{2}$ ) and refers to high-urbanized areas: almost three quarters of the population live in 40 major cities.

According to official statistics, the regions of the Central Federal District are characterized by asymmetry in socioeconomic development. In this regard, it seems relevant to smooth the differences in the development of the regions. For this, the formation of a single economic and the information space, common interests and development goals, research and implementation of best practices of the regions are of importance. An important component of the regional integration process is the monitoring of the living standards of the population of the regions.

The CFD is not only a geographical, but also financial center of Russia. Its economy is much diversified, but still, industry occupies a special place in it. The main branches of industrial specialization are knowledge-intensive and laborintensive production. The district occupies the leading positions in Russia in machine building and metalworking, textile industry. Among other branches of the national economy, agriculture (especially in the south of the district), construction, trade and public catering are distinguished. The Central Federal District is the leader among the federal districts in all key indicators of social and economic development. Important factors in the development of the social and economic sphere are the favorable economic and geographical situation, developed infrastructure and the created production and scientific and technical potential.

Moscow agglomeration (city Moscow and Moskovskaya oblast) takes the leading place in the economy of the district, providing $84 \%$ of revenues to the federal budget. Within the district, there is a big differentiation of the population income between this agglomeration and other regions (for example, tenfold between Moscow and Kaluzhskaya oblast).

The second group of regions with an average standard of living is represented by Belgorodskaya oblast, Lipetskaya 
oblast and Yaroslavskaya oblast. All three regions can be attributed to the industrial-developed regions, and have a predominantly industrial employment structure. Lipetskaya oblast, due to favorable climatic conditions and a developed agricultural sector, has one of the lowest costs of living among the regions of the Central Federal District.

Belgorodskaya oblast is characterized by a relatively low cost of living and more favorable conditions for the conduct of personal subsidiary farming; presence of export industries and enterprises of the fuel and energy sector provides revenues for the regional budget and a higher level of wages in the cities where they are located. Low unemployment and a high level of health lead to better indicators of life expectancy and infant mortality unlike the majority of the regions of the Central Federal District.

There are the following regions with a low standard of living included in the third group: Voronezhskaya oblast, Kaluzhskaya oblast, Kurskaya oblast, Orlovskaya oblast, Ryazanskaya oblast, Smolenskaya oblast, Tambovskaya oblast, Tverskaya oblast and Tulskaya oblast. Ryazanskaya oblast, Tulskaya oblast, Tverskaya oblast, Smolenskaya oblast and Kaluzhskaya oblast. They are similar in that they border directly with the highly developed Moskovskaya oblast and Moscow city. The relative proximity to the metropolitan agglomeration helps people living in border areas of the regions to find higher-paying jobs. Adaptation in the form of labor migration has reduced the tension in the labor markets of some districts. In addition, the above-mentioned regions are characterized by underdevelopment of small business and employment in it. Multiple backlog of wages from Moscow leads to the washing out of the most mobile and skilled personnel from the regions. A low level of improvement of housing stock is due to the predominance of small towns and many small villages in the settlement system.

The fourth group of regions with the lowest living standards is represented by Bryanskaya oblast, Vladimirskaya oblast, Ivanovskaya oblast and Kostromskaya oblast. All these regions have common problems: the slowdown in the development of the economic sphere, hence the high level of unemployment and lower incomes, as well as the aging of the population and the problems of its quality-low longevity, a low level of education for employed people, which does not provide the necessary mobility and competitiveness of workers. Vladimirskaya oblast and Ivanovskaya oblast have one of the lowest indicators of the living standard in the Central Federal District.

\section{LITERATURE REVIEW}

Income inequality might create a space for economic and social discrimination and that is a problem because it causes poverty. In recent days, there is no problem to obtain data about income inequality at the country level (in most cases it could be a Gini coefficient, well-known as one of the best inequality indicators), but relevant data at the regional level do not exist. Nevertheless, there is a sufficient set of research devoted to income inequality at the regional level.

Ayala, Jurado and Perez-Mayo in their paper analyze the extent to which poverty measures are sensitive to alternative ways of adjusting national lines by spatial price differences. First, they analyze how moving from national to regional poverty lines has an impact on the incidence and intensity of poverty. Second, they show how poverty patterns vary with alternative definitions of poverty thresholds. Using data from all Spanish regions, the authors' results show that regional levels of poverty change with each threshold, and the orderings of regions do not remain robust to the choice of poverty lines. They also show that re-rankings are more relevant for explaining differences in the regional distribution of poverty than gap-narrowing effects when a region-specific poverty line is used. A second finding resulting from probability models and decomposition methods is that poverty profiles vary as different lines are used. In general terms, their findings provide general support to the notion that poverty policies that do not address the problem of spatial price differences might yield relevant assignment errors. [1]

In the research of Jedrzejczak the main objective is to analyse regional inequalities in terms of household income distribution. The empirical evidence comes from the GUS, Istat and Bank of Italy databases and has been analysed by means of inequality and poverty indices calculated at NUTS 1 and NUTS 2 levels. In order to work out the intra-regional and interregional contributions to the overall inequality, the Gini index decomposition has been applied. While presenting similar levels of income concentration, Poland and Italy turned out to follow different regional inequality patterns. [2]

Vercueil tries to assess the impact of recent macroeconomic fluctuations on Russian household income levels. He goes deeper into the Russian case in order to show how regional disparities regarding incomes distribution can be interpreted, considering the country's recent macroeconomic trajectory. For this purpose, he builds a productive typology of the Russian regions and studies the link between each type and the level of income inequalities, using the varying structures in sources of household's incomes as a possible explanation of regional variations. [3]

Kim, Mohanty and Subramanian use multilevel logistic models for partition variation in poverty by levels of states, regions, districts, villages, and households in India. They also map the residuals at the state, region and district levels to visualize the geography of poverty using data on 35 states, 88 regions, 623 districts, 25,390 villages and 202,250 households from the National Sample Survey in the period of 2009-10 and 2011-12. They found $13 \%$ of the variation in poverty to be attributable to states, $12 \%$ - to villages, $4 \%$ - to districts and $3 \%$ - to regions, after accounting for important household characteristics. Similar variance partitioning was observed for the rural and urban sample. The relative importance of one contextual level was highly sensitive to other levels simultaneously considered in the model. Findings from this study suggest that further explorations using multilevel modeling are warranted to identify specific contextual determinants of poverty at the state and village levels to reduce poverty and promote balanced regional development in India. [4]

Hassine assesses the levels and determinants of economic inequality in 12 Arab countries using harmonized household 
survey micro-data. It focuses on the sources of rural urban, as well as metropolitan-nonmetropolitan, inequalities. The analysis finds moderate inequality levels, with Gini coefficient for the distribution of per capita total expenditures ranging between 30.7 in Libya and 45 in Mauritania. Differences in households' endowments such as demographic composition, human capital, and community characteristics appear as the main sources of the urban rural welfare gap. Inequality between metropolitan and nonmetropolitan regions is resulting mainly from differences in returns to human capital. [5]

Varvazovska and Prasilova in their paper analyze the development of the selected level of living indicators as related to households of the Capital of the Czech Republic and further it compares levels of special index numbers within EU. Distribution of wealth of the society is assessed using the Gini index number and the level of living is valued by means of the HDI (Human Development Index). The HDI is subdivided into the partial index numbers of health, education and income and the partial index numbers next give rise to the resulting HDI using gross domestic product. The region of the Czech Republic Capital presents very good results from the viewpoint of development tendencies and levels of the indicators assessed. Data sources have been obtained from the data banks of Czech Statistical Office, Eurostat and World Bank and have been processed using statistical methods from time series and index analysis area. [6]

Using the urban household survey data collected by the National Bureau of Statistics of China from 1988 to 2009, Chi examines the distribution, composition, and changes in capital income and its contribution to income inequality. The data show that capital income has increased considerably in the past 20 years in urban China. Although the average value of capital income is still relatively low, the dispersion of capital income is significant, and for high-income earners capital income is substantial. Compared to other forms of income, capital income is distributed the most unequally, and its contribution to total income inequality has been growing. His study also examines capital income in China's western, central, and eastern regions separately, and finds that capital income is highest and contributes mostly to income inequality in the eastern region. [7]

Using Oaxaca-Blinder decompositions at the mean as well as at different quantiles of welfare distributions on regionally representative household survey data from Brazil, Skoufias and Katayama find that household attributes account for most of the welfare differences between urban and rural areas within regions. However, comparing the lagging Northeast region with the leading Southeast region, differences in the welfare gains of attributes are associated with a large part of the welfare disparities, in particular in metropolitan areas, supporting the presence of agglomeration effects in booming areas. [8]

Keidel in his paper argues that more meaningful measures of regional disparities come from differences in regional poverty headcounts in China. He also suggests that higher regional inequality and accompanying interregional migration indicate that inequality plays an important positive role in inducing economic actors voluntarily to move to more productive locations and activities as a mechanism for ensuring sustainable improvements in individual well-being. [9]

Goerlich and Mas provide the methodology and results of a database of inequality indices for the fifty provinces and seventeen regions of Spain on the basis of the Household Budget Surveys for the years 1973/74, 1980/81 and 1990/91. The inequality indicators considered are the indices of Gini, Theil and Atkinson, as well as the distribution by deciles of the population. These indicators are drawn up for three variables: total income, total expenditure, and exclusively monetary expenditure. The variables are also expressed in terms of households, per capita and per capita equivalent. [10]

Analyzing household welfare in post-soviet Russia, most authors agree that with the beginning of transformation process both income inequality and amount of families with income below the poverty line increased substantially. In addition, many studies indicate a high level of poverty among households with a large number of children, as well as a high correlation between poverty and unemployment and a low level of education. Among them, research made by Klugman [11] can be mentioned. According to Klugman's work, the poorest categories of households in Russia in the 1990s were the families consisting of three or more children and families with one or more people with disabilities.

Speaking about a comparative study of poverty in Russia and other countries, it is worth mentioning Branko Milanović paper on poverty and inequality in transition economies [12] and research made by Bradbury, Jenkins and Mikelright [13]. Milanovic gives a description of the general processes that took place during the transition to a market economy in the CIS, Eastern Europe and the Baltic States, and the impact of these processes on the well-being of households. He also describes specific characteristics of poverty for each of these countries. Bradbury, Jenkins and Mikelright's paper is devoted to the study of long-term poverty among families with children in the US, Britain, Germany, Ireland, Spain, Hungary and Russia. The study shows that, compared to other countries, Russia in the late 1990s has the highest level of inequality in both income and expenditure for households with children.

Another research made by Korchagina and Ovcharova [14] concluded that the level of poverty determined by the Federal Service for State Statistics of the Russian Federation on the basis of the minimum consumer basket is lower by an average of $8-20 \%$ due to underestimation of economies of scale. Braithwaite and Ivanova [15] studied the relationship between long-term poverty and various demographic and regional characteristics of families, as well as unemployment or delays in the payment of wages.

The similarity of these works is that households are analyzed on the basis of the absolute poverty line. In this paper, the authors set the task of distributing households by equivalent incomes in the regions of the Central Federal District using relative poverty line. Absolute poverty is often contrasted with relative poverty, and their scales do not coincide. It is possible to eradicate absolute poverty, but not relative, since inequality is inherent in modern society. 
Measurement of relative poverty means exhibiting a relative poverty line and distributing population income towards it. As a relative poverty line, a certain proportion of the median per capita income (often $40 \%$ of the median income) is usually used, and all households from sample are distributed relative to it.

So, the first hypothesis for this research - most of households in all regions of Central Federal Distrcit belong to the third group, which is considered to be the middle class. Second hypothesis - in the majority of regions the proportion of households below the relative poverty line is less than $10 \%$. Third hypothesis - median equivalent income of households belonging to poor in terms of relative poverty does not exceed the subsistence minimum in the regions of the Central Federal District.

\section{METHODS OF RESEARCH}

Household Budget Survey being conducted by the Federal Service for State Statistics of the Russian Federation [16] is taken as a database for research in this paper. This survey is regionally representative and is carried out in all regions of the Russian Federation, except for the Chechen Republic.

The distribution of households is made by ranking them according to the scale of their equivalent incomes. There are five intervals on the scale. Since the relative concept of poverty is used, the median equivalent income $(M)$ is calculated for the entire household sample and $40 \%$ of this median is set as the boundary between the first and second interval (relative poverty line). The value of the median equivalent income is the middle of the third interval, and the other three boundaries with the same step are determined relative to it. As a result, the following formulas are obtained for calculating four scale boundaries:

- $\quad 0.4 * M$ - the boundary of the first and second intervals;

- $0.8^{*} M$ - the boundary of the second and third intervals;

- $1.2 * M$ - the boundary of the third and fourth intervals;

- $1.6 * M$ - the boundary of the fourth and fifth intervals.

As an indication of household income, equivalent income is used. It is calculated by authors on the basis of equivalence scales from Table 1, which are estimated by Beglova and Sadyrtdinov [17].

TABLE I. Estimated EQuivalence SCALES For CENTRAL FEDERAL DISTRICT REGIONS OF THE RUSSIAN FEDERATION

\begin{tabular}{|c|c|c|}
\hline $\begin{array}{c}\text { Household } \\
\text { composition }\end{array}$ & $\begin{array}{c}\text { Estimated } \\
\text { scale }\end{array}$ & Region of the Russian Federation \\
\hline 1 adult & 1 & All Russian regions \\
\hline \multirow{2}{*}{$\begin{array}{c}\text { to the second } \\
\text { adult }\end{array}$} & $0.25-0.4$ & $\begin{array}{c}\text { Bryanskaya oblast, Belgorodskaya } \\
\text { oblast, Ivanovskaya oblast }\end{array}$ \\
\cline { 2 - 3 } & $\begin{array}{c}\text { Ryazanskaya oblast, Tambovskaya } \\
\text { oblast, Kaluzhskaya oblast, } \\
\text { oblast, Yaroslavlskaya oblast, } \\
\text { Kurskaya oblast, Vladimirskaya } \\
\text { oblast, Voronezhskaya oblast }\end{array}$ \\
\cline { 2 - 3 } & $0.4-0.6$ & \begin{tabular}{c} 
Tulskaya oblast, Lipetskaya oblast, \\
\hline
\end{tabular} \\
\hline
\end{tabular}

\begin{tabular}{|c|c|c|}
\hline & & $\begin{array}{c}\text { Vologodskaya oblast, Tverskaya } \\
\text { oblast, Moskovskaya oblast }\end{array}$ \\
\hline & $>0.6$ & City Moscow, Smolenskaya oblast \\
\hline \multirow{3}{*}{ to each child } & $<0.25$ & $\begin{array}{l}\text { Lipetskaya oblast, Smolenskaya } \\
\text { oblast, Ryazanskaya oblast, } \\
\text { Orlovskaya oblast, Vladimirskaya } \\
\text { oblast, Belgorodskaya oblast, } \\
\text { Tambovskaya oblast, Kurskaya } \\
\text { oblast }\end{array}$ \\
\hline & $0.25-0.4$ & $\begin{array}{c}\text { Voronezhskaya oblast, } \\
\text { Kostromskaya oblast, Ivanovskaya } \\
\text { oblast, Kaluzhskaya oblast, } \\
\text { Tulskaya oblast, Yaroslavskaya } \\
\text { oblast, Pskovskaya oblast } \\
\end{array}$ \\
\hline & $>0.4$ & $\begin{array}{c}\text { City Moscow, Bryanskaya oblast, } \\
\text { Tverskaya oblast, Vologodskaya } \\
\text { oblast, Moskovskaya oblast }\end{array}$ \\
\hline
\end{tabular}

The equivalent income for households is calculated as a ratio of total household income for the month to the corresponding equivalence scale.

As an indication of the income measure, author used equivalent income, calculated on the basis of equivalence scales. The formula for calculating the equivalent income is as follows:

$$
E_{i}=\frac{H_{i}}{S}
$$

where $E_{t}$ - household equivalent income for the month,

$I_{t}$ - total household income for the month,

$S$ - equivalence scale.

Total household income for the month, age and gender of household members are taken from the Household Budget Survey in the Russian Federation for 2013. The survey covers the entire territory of the Russian Federation, with the exception of the Chechen Republic. The sample of households is regionally representative by all indications, including gender, age, geographic location, family composition. In 2013, survey presents data on 51320 households. Those of them who live in the regions of Central Federal District are all included in research, because needed parameters are outlined in the questionnaire.

\section{RESULTS AND DISCUSSION}

In order to take account of economies of scale in households, their per capita incomes were converted to equivalent incomes on the basis of equivalence scales taken from Table 1. Then, for all regions of the Central Federal District, the median values of the equivalent income were determined. The boundaries on the scale were estimated. All households were ranked along these intervals. The results of the distribution of households in the regions of the Central Federal District by equivalent incomes are presented in Table 2. 
TABLE II. HOUSEHOLDS DiSTRIBUTION IN CENTRAL FEDERAL DISTRICT REGIONS

\begin{tabular}{|c|c|c|c|c|c|}
\hline \multirow{2}{*}{ Region } & \multicolumn{5}{|c|}{$\begin{array}{l}\text { Households distribution by equivalent incomes, } \\
\%\end{array}$} \\
\hline & 1 group & 2 group & 3 group & 4 group & 5 group \\
\hline $\begin{array}{l}\text { Moskovskaya } \\
\text { oblast }\end{array}$ & 16 & 24.6 & 33.4 & 15.2 & 10.7 \\
\hline $\begin{array}{l}\text { Tambovskaya } \\
\text { oblast }\end{array}$ & 9.9 & 36.9 & 24.3 & 14.9 & 13.9 \\
\hline Kurskaya oblast & 5.8 & 33.3 & 33.3 & 18 & 9.5 \\
\hline $\begin{array}{l}\text { Yaroslavskaya } \\
\text { oblast }\end{array}$ & 5.1 & 42.6 & 27.5 & 13 & 11.8 \\
\hline $\begin{array}{l}\text { Voronezhskaya } \\
\text { oblast }\end{array}$ & 5 & 34 & 33.7 & 17.1 & 10.2 \\
\hline $\begin{array}{c}\text { Ryazanskaya } \\
\text { oblast }\end{array}$ & 4.1 & 34.8 & 33.5 & 18.1 & 9.5 \\
\hline $\begin{array}{l}\text { Kostromskaya } \\
\text { oblast }\end{array}$ & 3 & 37.5 & 33.6 & 15.6 & 10.5 \\
\hline $\begin{array}{l}\text { Vologodskaya } \\
\text { oblast }\end{array}$ & 2.9 & 42.9 & 31.7 & 12.3 & 10.2 \\
\hline Tverskaya oblast & 1.8 & 39.4 & 35.3 & 13.9 & 9.7 \\
\hline $\begin{array}{l}\text { Bryanskaya } \\
\text { oblast }\end{array}$ & 1.8 & 41.7 & 29.4 & 15.9 & 11.1 \\
\hline $\begin{array}{l}\text { Kaluzhskaya } \\
\text { oblast }\end{array}$ & 1.4 & 42.4 & 30.6 & 13 & 12.6 \\
\hline City Moscow & 1.3 & 37.5 & 39.7 & 13.6 & 7.9 \\
\hline $\begin{array}{c}\text { Lipetskaya } \\
\text { oblast }\end{array}$ & 1.2 & 43.5 & 28.3 & 12.4 & 14.6 \\
\hline $\begin{array}{c}\text { Orlovskaya } \\
\text { oblast }\end{array}$ & 1.1 & 46.3 & 31.9 & 9 & 11.7 \\
\hline $\begin{array}{l}\text { Vladimirskaya } \\
\text { oblast }\end{array}$ & 0.8 & 44.2 & 29.3 & 15.1 & 10.6 \\
\hline $\begin{array}{c}\text { Ivanovskaya } \\
\text { oblast }\end{array}$ & 0.7 & 41.1 & 35.4 & 13.6 & 9.2 \\
\hline $\begin{array}{l}\text { Belgorodskaya } \\
\text { oblast }\end{array}$ & 0.4 & 41.2 & 33.5 & 15.1 & 9.8 \\
\hline Tulskaya oblast & 0.3 & 38.3 & 37.8 & 14.5 & 9.1 \\
\hline
\end{tabular}

Table 2 shows that in two regions of the Central Federal District (Moskovskaya oblast and Tambovskaya oblast), the proportion of households below the relative poverty line is about $10 \%$ and more. There are four regions (Vladimirskaya oblast, Ivanovskaya oblast, Belgorodskaya oblast, Tulskaya oblast) where household proportion below the relative poverty line is less than $1 \%$. Other regions could be divided into two groups. In the first group, including Kurskaya oblast, Yaroslavskaya oblast, Voronezhskaya oblast, Ryazanskaya oblast, Kostromskaya oblast and Vologdskaya oblast 2.9-5.8\% of households from the whole sample, is below the poverty line. The second group (Tverskaya oblast, Bryanskaya oblast, Kaluzhskaya oblast, Lipetskaya oblast, Orlovskaya oblast and city Moscow), the proportion of households who are poor in terms of relative poverty, is within $1.1-1.8 \%$.

In almost all regions, most households belong to the second group, which is considered to be the lower-middle class. The proportion differs through the regions, but on average, it is $40 \%$ from the whole sample. Only in Moskovskaya oblast and Moscow city, most of households are in third group, which can be called the middle class.

Analyzing the third group, it can be mentioned that the proportion of households belonging to this group differs through regions and is within 24.3-39.7 \% of the whole sample. It is less than $30 \%$ in Tambovskaya oblast, Yaroslavskaya oblast, Bryanskaya oblast, Lipetskaya oblast and Vladimirskaya oblast. The number of households belonging to the middle class exceeded $40 \%$ in none of the regions (only city Moscow was close to this).

The upper-middle class represented in group 4 does not exceed $20 \%$ and is within $9-18.1 \%$ (on average $14.5 \%$ ) in all regions of Central Federal District. Only in two regions, Lipetskaya oblast and Orlovskaya oblast, the proportion of households in the upper-middle class (group 4) is higher than in the upper class (group 5). In all other regions, the situation is opposite.

Comparing the distribution of households in different regions among five groups, it is necessary to note approximately equal proportion of household distribution in the fourth and fifth groups and significant differences in the first and third groups. It indicates that some regions are more successful in reducing relative poverty, but no one can significantly increase the number of households with incomes above the average. Only in two regions, the share of households belonging to the third group is higher than the proportion of those who fell to the second group.

Officially, to determine the level of poverty in Russia, a subsistence minimum (SM) is used. Until 2013, the procedure for determining the amount of the subsistence minimum and its purpose was regulated by Federal Law No. 134-FZ of 24.10.1997 "On the Subsistence Minimum in the Russian Federation". The amount of the subsistence minimum was a valuation of the consumer basket, as well as compulsory payments and fees [18]. The subsistence minimum and median monetary incomes of the households from five groups are presented in Table. 3. Estimating the data of the table, it is easy to see that per capita equivalent incomes do not exceed the subsistence minimum only in first group. However, this does not indicate the general well-being of the population. The reality is that this amount of the subsistence minimum is impossible to live on, but survive; one can spend money on a very modest livelihood, paying for utilities. Non-food products by the amount of the subsistence minimum cannot be purchased.

In 2013, a new procedure for calculating the consumer basket began, on the basis of which the subsistence minimum is calculated. According to the approved document, the minimum set of food products is now measured in natural terms. At the same time, the cost of non-food items that are included in the consumer basket is defined as half of the cost of food. Another quarter of the total cost of the basket comes from consumed services.

Previously, the value of non-food items was calculated in physical terms. For example, how many pieces of clothing a person should use for a year. The new order of calculation, as explained in the resolution, allows for real changes in the cost of non-food goods and services in the consumer basket.

From 2013, the annual grocery kit for working population includes $126.5 \mathrm{~kg}$ of bread products, more than $100 \mathrm{~kg}$ of potatoes, $60 \mathrm{~kg}$ of fruit and $114.6 \mathrm{~kg}$ of vegetables, as well as 
$58.6 \mathrm{~kg}$ of meat and $18.5 \mathrm{~kg}$ of fish, 290 liters of dairy products and 210 eggs.

TABLE III. MEDIAN INCOME FOR FIVE GROUPS OF HOUSEHOLDS IN CENTRAL FEDERAL District REgIONS

\begin{tabular}{|c|c|c|c|c|c|c|}
\hline \multirow[b]{2}{*}{ Region } & \multirow[b]{2}{*}{ SM } & \multicolumn{5}{|c|}{ Median equivalent income, Russian Rubles } \\
\hline & & 1 group & $\underset{\text { group }}{2}$ & $\begin{array}{c}3 \\
\text { group }\end{array}$ & 4 group & $\begin{array}{c}5 \\
\text { group }\end{array}$ \\
\hline $\begin{array}{c}\text { Belgorodskaya } \\
\text { oblast }\end{array}$ & 6106 & 3740.7 & 14523 & 23887 & 33828.7 & 53979 \\
\hline $\begin{array}{c}\text { Tambovskaya } \\
\text { oblast }\end{array}$ & 5230 & 3846 & 8306.9 & 13068 & 18141.6 & 28787 \\
\hline $\begin{array}{c}\text { Kurskaya } \\
\text { oblast }\end{array}$ & 5925 & 4725.6 & 9506.6 & 14620 & 20747 & 32042 \\
\hline $\begin{array}{c}\text { Voronezhskay } \\
\text { a oblast }\end{array}$ & 6043 & 4741.4 & 9448.7 & 15312 & 21927.1 & 33014 \\
\hline $\begin{array}{c}\text { Orlovskaya } \\
\text { oblast }\end{array}$ & 6443 & 4905.8 & 13379 & 21583 & 30067.2 & 51867 \\
\hline $\begin{array}{c}\text { Kostromskaya } \\
\text { oblast }\end{array}$ & 6916 & 5010.6 & 10870 & 17732 & 24744.3 & 40888 \\
\hline $\begin{array}{l}\text { Lipetskaya } \\
\text { oblast }\end{array}$ & 6215 & 5075.8 & 11743 & 19698 & 28100.6 & 42167 \\
\hline $\begin{array}{c}\text { Bryanskaya } \\
\text { oblast }\end{array}$ & 6543 & 5188.2 & 13399 & 22317 & 226.7 & 47932 \\
\hline $\begin{array}{c}\text { Yaroslavskaya } \\
\text { oblast }\end{array}$ & 6500 & 5292.2 & 10881 & 17328 & 24280.4 & 41371 \\
\hline $\begin{array}{c}\text { Vologodskaya } \\
\text { oblast }\end{array}$ & 7474 & 5446.3 & 11984 & 18938 & 26413.4 & 49274 \\
\hline $\begin{array}{c}\text { Ryazanskaya } \\
\text { oblast }\end{array}$ & 6677 & 5618.9 & 9477 & 14939 & 20639.2 & 30316 \\
\hline $\begin{array}{c}\text { Kaluzhskaya } \\
\text { oblast }\end{array}$ & 6682 & 5671.9 & 12490 & 21429 & 29327.5 & 46100 \\
\hline $\begin{array}{c}\text { Moskovskaya } \\
\text { oblast }\end{array}$ & 8072 & 6010.5 & 10648 & 15775 & 21951.3 & 36362 \\
\hline $\begin{array}{c}\text { Tverskaya } \\
\text { oblast }\end{array}$ & 7121 & 6115.9 & 12474 & 19647 & 27729.2 & 44250 \\
\hline $\begin{array}{c}\text { Tulskaya } \\
\text { oblast }\end{array}$ & 6740 & 6230.9 & 13290 & 19764 & 27240.6 & 40748 \\
\hline $\begin{array}{c}\text { Vladimirskaya } \\
\text { oblast }\end{array}$ & 6989 & 6245.4 & 13021 & 21553 & 29981.1 & 50043 \\
\hline $\begin{array}{c}\text { Ivanovskaya } \\
\text { oblast }\end{array}$ & 7036 & 6263.2 & 15021 & 24454 & 34329.1 & 59234 \\
\hline City Moscow & 10965 & 8420.6 & 18149 & 27711 & 38607.7 & 66266 \\
\hline
\end{tabular}

One of the important moments is the high differentiation of living standards between regions of Central Federal District. The situation of the poor in today's Russia is worsening by the growing level of socioeconomic inequality, which significantly limits the ability of people to get out of poverty. It is clear that it is impossible to radically change the situation with an increase in the standard of living of the population, but it is necessary to gradually raise the minimum wage, bringing the subsistence level to a level where the citizen could satisfy one's needs at the required level. It is also important to continue the social policy, where an important place should be given to social protection of the households, the implementation of social guarantees, pensions, medical insurance.

\section{CONCLUSION}

Based on the research, the following conclusions are made:

1. In almost all regions most households belong to the second group, which is considered to be the lower-middle class. The proportion differs through the regions, but on average, it is $40 \%$ from the whole sample. Only in Moskovskaya oblast and Moscow city, most of households are in the third group which can be called the middle class. The first hypothesis is refuted.

2. In the majority of Russian regions, the proportion of households below the relative poverty line is less than $10 \%$. The second hypothesis is confirmed.

3. Median equivalent income of households belonging to poor in terms of relative poverty does not exceed the subsistence minimum in the regions of the Central Federal District. The third hypothesis is confirmed.

\section{Acknowledgment}

This work was supported by the research grant of Kazan Federal University.

\section{References}

[1] L. Ayala, A. Jurado and J. Perez-Mayo, "Drawing the Poverty Line: Do Regional Thresholds and Prices Make a Difference?", Applied Economic Perspectives and Policy, vol. 36, no. 2, pp. 309-332, 2014.

[2] A. Jędrzejczak, "Regional Income Inequalities In Poland And Italy, Rozkład Nierówności Według Regionów w Polsce i We Włoszech", Comparative Economic Research, vol. 18, no. 4, 2015.

[3] J. Vercueil, "Income Inequalities, Productive Structure and Macroeconomic Dynamics. A Regional Approach to the Russian Case", Economic and social changes: facts, trends, forecast, no. 345, 2016.

[4] R. Kim, S. Mohanty and S. Subramanian, "Multilevel Geographies of Poverty in India", World Development, vol. 87, pp. 349-359, 2016.

[5] N. Hassine, "Economic Inequality in the Arab Region", World Development, vol. 66, pp. 532-556, 2015.

[6] Y. Yorozu, M. Hirano, K. Oka, and Y. Tagawa, "Electron spectroscopy studies on magneto-optical media and plastic substrate interface," IEEE Transl. J. Magn. Japan, vol. 2, pp. 740-741, August 1987 [Digests 9th Annual Conf. Magnetics Japan, p. 301, 1982].

[7] W. Chi, "Capital income and income inequality: Evidence from urban China", Journal of Comparative Economics, vol. 40, no. 2, pp. 228-239, 2012.

[8] E. Skoufias and R. Katayama, "Sources of welfare disparities between and within regions of Brazil: evidence from the 2002-2003 household budget survey (POF)", Journal of Economic Geography, vol. 11, no. 5, pp. 897-918, 2010.

[9] A. Keidel, "Chinese Regional Inequalities in Income and Well-being", Review of Income and Wealth, vol. 55, pp. 538-561, 2009.

[10] F. Goerlich and M. Mas, "Inequality in Spain, 1973-91: Contribution to a Regional Database", Review of Income and Wealth, vol. 47, no. 3, pp. 361-378, 2001.

[11] J. Klugman, "Poverty in Russia: An assessment", World Bank Report, No. 14110-RU, 1998.

[12] B. Milanovic, Income, inequality and poverty during the transition from planned to market economy. Washington, D.C.: The World Bank, 1998.

[13] B. Bradbury, S. Jenkins and J. Micklewright, Child poverty dynamics in seven nations. Florence: Unicef, United nations children's fund, Innocenti resarch centre, 2000.

[14] I. Korchagina and L. Ovcharova, Indicators of poverty in transitional Russia. Moscow: Economic Education and Research Consortium, 1998.

[15] J. Braithwaite and A. Ivanova "Economies of Scale \& Poverty Lines: Russia 1994-1996", Moscow: The World Bank, 1998.

[16] Budget Survey of Households in Russian Federation 2012, Retrieved from: http://obdx.gks.ru/

[17] R. Sadyrtdinov and E. Beglova, "Equivalence Scale Estimation for Regions of the Russian Federation". In Kliestik T, editor, Globalization and its Socio-economic Consequences, 16th International Scientific 
Conference Proceedings, PTS I-V. University Zilina, Faculty Operation \& Economics Transport \& Communication, 2016, pp. 734-740.

[18] R.M. Nurtdinov, A.R. Nurtdinov, N.K. Gabdrakhmanov, Ecologyoriented enterprises as integral elements of sustainable development of the Russian Federation, Business and management, Book 1 Modern
Science, VOL III, Book Series: 4th International Multi-disciplinary Scientific Conference on Social Sciences and Arts, pp. 341-346. 